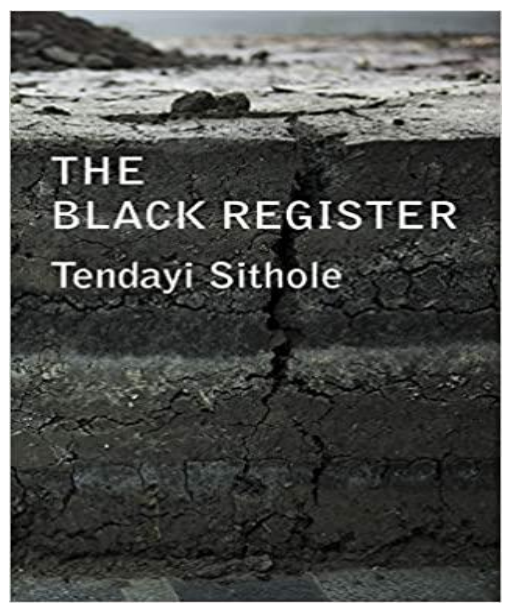

Sithole, T. (2020). The Black Register. Polity Press. ISBN-10: 150954206X; ISBN: 978-1-5095-4206-2 (hardback). 282p. $\$ 69.95$

\title{
The Pursuit of Being: Reflections on Blackness
}

\author{
Bruno Halpern ${ }^{1}$ \\ Florida Gulf Coast University, USA
}

\begin{abstract}
The Black Register calls for the uprooting of a world structured by the systems of oppression imposed by whiteness throughout the centuries. Colonialism, imperialism, and racism have long been weaponized against black-skinned peoples, denying them life and voice. In this book review, the author analyzes Tendayi Sithole's propositions to establish a new world system where blackness will not be lifeless or voiceless anymore.
\end{abstract}

Keywords: blackness, colonialism, imperialism, racism, whiteness.

\section{Introduction}

The Black Register, by Tendayi Sithole (2020), is blacks' claim to voice and write a destiny of their own. Through compelling and, at times, forceful rhetoric, Sithole invites the reader to ponder about our place in the world, our ancestry, and change. Sithole is not preoccupied with readers' past convictions and personal truths. He aims to shatter assumed conventions and replace them with something radically new, almost utopian. The Black Register is a challenging book, and each page deserves careful consideration, for its message is potentially disruptive of social norms and laws. A whole spectrum of divergent and clashing opinions can surely be expected from anyone who immerses in these pages, especially when identity, experiences, and beliefs come into the forefront. In each chapter, Sithole analyzes the ideas of authors identified with black movements, especially black existentialism, Négritude, and Black Consciousness. Some will view this book as a manifesto - a call to action-while others will dismiss it as elucubrations of an unhinged radical thinker. Regardless, The Black Register will engage readers to go to unexpected mindscapes to find uncomfortable truths. 


\section{Summary}

In chapter one, Sithole delved into the work of Sylvia Wynter, a Jamaican philosopher, and novelist, whose insights about blackness and the consequences of colonialism in the unmaking of blacks of their human status reverberated in black studies and the philosophical world. Sithole focused on Wynter's notion of nonconformity as the only way for a new epistemic pathway to emerge and end the European model of humanity - the Imperial Man whose actions were legitimized by colonization, resulting in his idea of being hierarchically, technologically, and spiritually superior to all.

In this context, the structure of oppression against blacks was purposefully put in place in his persistent colonization wake, negating black's society, language, and customs. Thus, an After Man must come to overthrow the unnatural and distorted Imperial Man; one that leads the way and engages in revolutionary acts that rupture the norm, by clinging to blackness, black philosophy, black speech, and black identity to dismantle the foundations of the imperial structure and dehumanization by the standardization of European attributes.

Aimé Césaire's négritude movement to raise and cultivate blackness awareness, was Sithole's focus on chapter two. He was from Martinique and rose to prominence through his poetry, playwriting, and as a politician. Sithole highlighted Césaire's criticism and skepticism over Europe's material and intellectual contributions to the world, considering it a narcissistic, diseased civilization that survived by incentivizing a cultural and religious genocide, dehumanizing and destroying the Other. In this view, Europe would be the only accurate measure of advancement and progress, creating an adversarial framework that forces its fallacious universalist model onto other civilizations.

In chapter three, Sithole brought forth Biko, a South African anti-apartheid activist who was brutally murdered while in custody, trying to dismantle a system of oppression that outlawed him for the color of his skin. When the White supremacist regime ended, the new South African government glorified Biko and other anti-apartheid activists. Still, to Sithole, this was a faux attempt to restrain Biko's ideas. Thus, his life and struggle were pacified and muzzled, as if the antiblack world was over. For Sithole, Biko cannot be considered a martyr since his blackness condemned him to a lifeless life. His politics and ideas were whitewashed and made feel as if the issues he fought and died for were already resolved. Thus, after the end of apartheid, the structure of White supremacy remained, hiding behind black faces. Its purpose was not through a black revolution, impeding an actual uprooting of antiblackness. Instead, it was led by a white initiative as a way to control the process and maintain the structure that allowed it to rule.

Sithole claimed that racism will not be over until the antiblack world ceases to exist. Whiteness extracts everything from blackness, and blackness, depleted, becomes non-existent, while Whiteness is invigorated. While other races face similar racist hate from Whites, none has suffered quite in the same intensity as blacks. Sithole concluded that blacks should speak for blacks because Whiteness cannot produce an outcome that will be beneficial to blackness. The anti-racist projects are White so that they will bear no benefit to blackness.

In the following chapter, Sithole presented two important leaders of the 1960-1970s black revolutionary movement in the United States; Assata Shakur and George Jackson exemplify what Sithole called the "prison slaves," establishing prisons as an extension of slavery. The police and the FBI relentlessly targeted Shakur and Jackson. While Jackson died in prison, Shakur escaped and fled to Cuba. Both used the written word to shatter the shackles that perpetuate black bodies in the prison slave condition. There can be no real justice in the antiblack world. There is no fair 
trial when Whiteness composes the jury and commands the judge. Sithole wanted the reader to see Shakur and Jackson as noble figures because of their love toward their cause to save blackness and end of the pathological life that leads to the existence of the prison slave-deliberately designed by the antiblack world. In his view, Blackness is also excluded from grammar. It is relegated to the zone of non-existence, constituting lacks and deficits that prevent it from being a subject in the full sense of the word. This corrupt constitution is designated to legitimate the ontological-existential violence that shapes the antiblack world. Blackness must emerge through the politics of resurrection. Paradoxically, those who live in a black condition face the challenge of being politically deprived of being subjects in possession of their lives. In truth, they are not citizens, but blacks.

Sithole cited Althusser's framework to remind the reader that the repressive state apparatus exerts machinery subjection at a micro-political level which provokes dehumanization, mainly, in the service of the antiblack world, preventing significant changes to occur, except cosmetic ones. The state apparatus' role is to execute violence, especially against black bodies, endorsed by the instrument of the state, the law. And, at a macro-political level, the repressive state agents are means in the service of the massive structure within the antiblack world. Black subjection is a congenital condition of lack that cannot end with the end of the state; it is implanted in the antiblack infrastructure of the world, trapped by forces that will assure its reproduction, and that will always keep subjection and its spread.

Mabogo P. More was Sithole's focus on chapter five, a South African philosopher, proponent of black existentialism or Africana critical theory. Philosophy is often unconcerned with racial matters, but Sithole argued that opposition to this notion cements antiblack racism. The Africana existential philosophy imagines and builds a new world where blackness is not anymore subjugated. Thus, existential conditions are considered as a primary source of inspiration. In this sense, Western philosophy was constructed for and by Whiteness, negating blackness in its theories and discourses and, thus, being complicit in racism. In other words, antiblackness has ensnared many blacks themselves, which manifests as self-hate, violence against other blacks, or through seeking whiteness' approval.

Within the Manichean structure lies whiteness versus blackness, in which the former defines what is human and non-human, superior and inferior, good and evil, keeping an asymmetrical relationship. Whiteness is the master signifier, constructing blackness through subjection, while oppressing and dehumanizing its very existence. Sithole highlighted Hudson's "colonial unconscious" (as cited in Sithole, 2020, p. 246) to explain the racist fantasies and phobias about blackness, which reinforces this experience.

Finally, in chapter six, Sithole referred to the Marikana massacre as an episode that articulated the extent violence and dehumanization can go to liquidate black life. It showed what occurs when impunity reigns. This incident enabled the understanding that blackness is always interdicted because life itself is dispossessed by those that have no right to pursue their own lives. Thus, Sithole cited Giorgio Agamben's concept of bare life to understand the politics of life in peripheral zones, though he emphasized that this concept is insufficient to engage the very ontology of black subjects when it suffers a sort of conceptual anxiety.

In this realm, the black subject is reduced to a body that represents an object. This objectification legitimized the deathscape in which the destruction of black life is inherent and entrapped in the state of killability that is justified through law and order. This invisible form of violence exemplifies the very basis of deathscapes like Marikana's, normalizing and naturalizing it, erasing the race question from discussion and change. 


\section{Review}

With The Black Register Sithole dissected the antiblack world, created and fomented by the pervasive influence of White supremacy in society that strips black people of their humanity (Steinberg \& Kincheloe, 2001). In each chapter, Sithole analyzed the lives and ideas of black authors and how their experiences shaped the modern black experience. He concluded that blacks have no place in a world built for and by Whites, whose structure aims to subjugate them to maintain White privilege and power.

It is in good measure to congratulate the author for his courage. A topic of this magnitude and gravitas deserves more eloquent voices, such as Sithole's, to disseminate its complexities to a broader audience. Sithole was also timely to publish the Black Register during one of the most massive anti-racism demonstrations in the United States' history following the murder of George Floyd.

The Black Register is not an easy book to grasp when one is accustomed to being entrenched in a world forged by Whiteness. It will be particularly hard for readers unfamiliar with Africana Critical Theory (Bassey, 2007), black existentialism, the Négritude (Césaire, 1997) and Black Consciousness Movement (Gordon, 2008), modern South African history, colonialism, and imperialism. The author was confident that readers would be on the same page as him or would eventually catch up by doing research themselves. This might have the negative effect of breaking the reading pace and overwhelming a less engaged reader. A page or two providing context to some of the themes and philosophical frameworks would be helpful to those beginning their journey into themes of White supremacy, anti-blackness, colonialism, and imperialism.

However, the world can be far more complex to paint it as a harsh black-and-white dichotomy where Europe produced only evil and no good. The ill-intent of Europeans, especially during the high of colonization, was well-documented and ever more popular among even those who are unfamiliar with history (perhaps thanks to men like Césaire); but to cast such negative light over a whole continent, "race," could be interpreted by some readers as reductionist.

It is worth noting that Sithole - and the entire movement he speaks for-did not seem interested in defining what "blackness" is, limiting his stance to skin color. If he is, it was not clear in this book. He classified blackness as homogeneous and did not explore the multitude of factors that distinguish black people from each other, such as culture, religion, nationality, and points of view. It is important to highlight that every person has a particular set of experiences that are shaped by cultural currents that permeate his or her life. Reality does not emerge from a single source, and, therefore, it is not monolithic (Barth, 2000). Individuals are the product of social interactions (Blumer, 1986; Mead, 1982), and reality is socially constructed (Berger \& Luckmann, 1985). People are immersed in a web of significance (Weber \& Heydebrand, 1994), or, better still, a web of social meanings (Geertz, 1973).

And even within "black" as a phenotype, there are hundreds of varying skin tones, facial traits, hair types that make the task of fitting all blacks into a box called "blackness" impossible. The same would apply to Whiteness or any other race. Additionally, how one defines his or her own race can be a complicating matter, since race and its meanings and discourses are socially and historically constructed as well as a continuous process of being, of 'finding' one's own identity.

Another element that is worth pointing out is the author's desire to exclude Whites (and assumingly other races) from the effort of ending White supremacy. While the author's willingness to guarantee blackness' headship was valid and necessary, it does not exist in a vacuum. The author cannot control how these ideas will spread or how they will be implemented. Furthermore, what 
Sithole identified as the root causes for the existence of the antiblack world could perhaps be better explained by the human instinct of self-preservation through social segregation, where one group is elevated as the established ruling class and, the others, as the outsiders (Elias \& Scotson, 2000).

Sithole argued that, "Black existence continues to be militated against by the black elite who are managers and guarantors of neo-apartheid with its infrastructure of white supremacy" (Sithole, p. 211). Therefore, it is not a matter of race, but the combination of elements of class, power, and the almost inescapable human characteristic of greed and selfishness that are at play in matters of discrimination and subjugation. Consequently, the system that oppresses blacks in an anti-black world will always find a way to restore its balance to keep blacks subordinated to Whites, seeking its autoregulation in the face of any attempt to change (Hoyle, 1985). For that reason, the solutions proposed by Sithole might feel utopian to some readers, but surely most of them will agree that the overarching themes deserve to be taken seriously. Discussions centered on structural racism and how it affects blacks more so than other discriminated groups are fundamentally important in today's world. Progress starts with books like the Black Register, allowing these problems to be brought to light and, hopefully, solved once and for all.

\section{References}

Barth, F. (2000). A análise da cultura nas sociedades complexas [An analysis of the culture of complex societies]. In T. Lask (Org.), $O$ guru, o iniciador $e$ outras variações antropológicas [The guru, the iniciator, and other anthropological variations] (pp. 107139). Contra Capa Livraria Ltda.

Bassey, M. O. (2007). What is Africana critical theory or Black existential philosophy? Journal of Black Studies, 37(6), 914-935.

Berger, P. L., \& Luckmann, T. (1985). A construção social da realidade: Tratado de sociologia do conhecimento [The social construction of reality: Treaty of the sociology of knowledge]. Editora Vozes.

Biko, S. (2002). I write what I like. The University of Chicago Press.

Blumer, H. (1986). Symbolic interaction: Perspective and method. University of California Press. Césaire, A. (1997). Return to my native land. Bloodaxe Books.

Elias, N., \& Scotson, J. L. (1994). The established and the outsiders (2nd ed.). SAGE Publishing. Geertz, C. (1973) The Interpretation of Cultures. Basic Books, Inc., New York.

Gordon, L. R. (2008). An introduction to Africana philosophy. Cambridge University Press.

Hoyle, E. (1985). [Review of the book Structuralism and Education, by Rex Gibson]. British Journal of Educational Studies, 33(2), 183-185. https://doi.org/10.2307/3121513

Mead, G. H. (1982). The individual and the social self: Unpublished essays by G. H. Mead. Ed. by David L. Miller. University of Chicago Press.

Rabaka, R. (2010). Africana critical theory: Reconstructing the Black radical tradition: From W.E.B. Du Bois and C.L.R. James to Frantz Fanon and Amilcar Cabral. Lexington Books.

Sithole, T. (2020) The Black register. Polity Press.

Steinberg, S., \& Kincheloe, J. (2001). Setting the context for critical multi/interculturalism: The power blocs of class elitism, white supremacy, and patriarchy. In S. Steinberg (Ed.), Multi/intercultural conversations: A reader (pp. 3-30). Peter Lang Publishing.

Weber, M., \& Heydebrand, W. (Ed.). (1994). Sociological writings: Max Weber. Continuum International Publishing Group. 


\section{Notes on Contributors}

Originally from Rio de Janeiro, Brazil, Bruno Halpern is doing a master's in Educational Leadership at Florida Gulf Coast University. He has a Bachelor's in Journalism. He's been a citizen-board member at The News-Press, a radio newsroom intern at WGCU, and an editor for ABC/NBC TV. He also recently won the Florida Association of Broadcast Journalism Award for Best Sound. 